\title{
Discussion on the Relationship Between Humanism and Art
}

\author{
Sihan Zhang ${ }^{1, *}$ Ying Wang ${ }^{1}$
}

${ }^{1}$ Sichuan Agricultural University, Ya'an, Sichuan 625000, China

*Corresponding author. Email: 695029724@qq.com

\begin{abstract}
Humanism thoughts appeared in the classical period, and emerged in the Renaissance period. To modern times, artists created works adhering to the design principle of people-oriented. The influence of humanism on art is particularly obvious in the development history of installation art. And the function of art counteracts humanism. Only by grasping the connotation of humanism and handling the relationship between humanism and art can artists create more valuable works of art.
\end{abstract}

\section{Keywords: humanism, principle of people-oriented, art, installation art}

\section{INTRODUCTION}

From the classical era to today, humanism has always been an important idea in art design, and the people-oriented spirit has always been valued by artists. It can be said that humanist ideas have promoted the progress and development of art. If people's needs are neglected, and art creation no longer pays attention to the principle of people-oriented, then art will be water without a source, and wood without a root.

\section{HUMANISM IN THE HISTORY OF ART DEVELOPMENT}

\section{A. Classical period}

The concept of humanism appeared in the early classical period. The strong humanistic atmosphere filled the classical culture at that time. The focus and object of culture were people, and society began to value people's own values. The ancient Greeks began to think that "the most wise and beautiful person is a symbol of God" and "people are close to God as friends". They think that God is close to people and has a tacky desire like humans. The character of God is not perfect, but as diverse and even flawed as humans. The most ideal appearance of human was regarded as the image of God by the ancient Greeks, and God was no longer unreal. In the mythology described by the ancient Greeks, God and human can even love each other, and God was more like the existence of human interests. While praising God, the ancient Greeks paid more attention to praising people, emphasizing the value of human dignity. Such humanistic ideas quickly penetrated into the literature and art of the time, and in the works at that time, the artist affirmed and praised the value of humans everywhere.
The red-painted work "Ceramic Cup of Music Classes" exhibited in the Berlin Archaeological Museum today allows people to get a good understanding of the creative tendency and characteristics of artists at that time. The work depicts the scene of Greek students taking music lessons at the time. A group of students are listening to the teacher's skills in playing musical instruments and singing. The students' expressions are different. Some are serious, and some are frowning and thinking. It can be seen that the artist attached great importance to the depiction of facial expressions and was very accurate in character modeling. It can be said that the "Ceramic Cup of Music Classes" is an important manifestation of the humanism in the classical period. Artists at that time no longer focused solely on architecture and sculpture, but began to create related works for people. Works often showed people's ordinary lives and activities.

\section{B. Renaissance period}

By the Renaissance period from the 14th to the 16th century, the influence of humanism expanded and people's understanding of humanism was more profound than before. Artists began to demand that art should be free from religious belief, that creation should be more free, and that people's spirits should also be freed from imprisonment by feudal forces. The humanists of this period were full of admiration for the humanism of the classical period. In order to study the theories of the time, they began to study ancient Greek independently, and enthusiastically collected classic works of the time. Most of the inspiration of the Renaissance authors came from these documents.

The core idea of the Renaissance was humanism. Under the impetus of this idea, the authority of God was questioned. People realized the importance of pursuing the happiness of real life and began to value 
their sensory perception. This core idea also produced many immortal paintings during the Renaissance. For example, Da Vinci's "Last Supper": The 13 people in the painting have different poses, different appearances, obvious personality characteristics, the whole picture is full of drama, the expressions and actions of the characters correspond to each other, and the picture seems to be dynamic drama. Da Vinci paid attention to the use of light in the picture and used light to enhance the visual perception of the audience. The excellent light and shadow effect makes the characters, objects and backgrounds in the painting have a threedimensional realism.

Renaissance art no longer floated on the surface, but began to penetrate into people's hearts and show people's inner world in their works. These are the results of the continuous deepening of humanistic thinking during this period.

\section{Enlightenment period}

During the enlightenment period from the 17th century to the 18th century, humanist ideas reached new heights. People began to pursue equality, emphasized democracy, and opposed authoritarian rule. In this period, it respected personal freedom and personal interests.

At this time, people were no longer bound by religion, and they took rationality as their banner, hoping to build a rational society, emphasizing "natural human rights," humanism thoughts were involved in almost all areas of art, and the will of the people was increasingly valued. Under this influence, works of art began to depict the lives of ordinary people in large quantities, and the works were more realistic.

\section{The period from the end of the 19th century to the present}

With the development of the times, people's material life standards have improved, and the abundance of material life has enabled people to better pursue high-quality spiritual life. The connotation of humanism has been constantly enriched, and the influence of the humanistic spirit has also increased. In terms of aesthetics and design, the influence of humanism becomes more obvious. People are paying more and more attention to emotions and spirits, and are beginning to seek the art of change with multiple sensory interactions. This pursuit has spawned installation art. Installation art is an innovative art form. Unlike traditional art, the display effect of installation art is closely related to the spatial environment of the display. The surrounding environment is also part of the work, so installation art is also called "environmental art". Installation art is the continuation of people's life experience and an important part of multimedia art. The so-called multimedia art refers to the use of television, video and Internet to create works, and then spread to the public in this form of art. This art is of strong timesensitive. Therefore, paying attention to the audience's feelings and establishing a humanized environment is an important element that installation art should pay attention to.

Installation art is constantly changing art. As far as installation art is concerned, the existence of the audience is not only simply appreciation of the work, but many times the audience is also a part of the work. Installation art does not belong to a certain art category alone, and the display of works often requires a corresponding independent space so that the audience can enter it and narrow the psychological distance from the audience. For the audience, this is an immersive experience process. Installation art uses this creative method to make the audience no longer an outsider, making them change from the passive appreciation of the past to the current active feeling, and even becoming a part of the artwork. The social participation of the art has been greatly improved. This kind of work emphasizes the relationship between people more deeply and penetrates into the inner world of the audience. In the independent space, the artist and the audience collide emotionally.

A French postman named Cheval is the first person to use existing materials to express the concept of installation art. During the 19th century, Cheval spent more than 20 years building a strangely shaped palace called "Ideal Palace" with cement, shells, and stones. The palace occupies a large area, and the building materials are his collections on the way back and forth. Cheval used installation art to reconstruct the common cement and stone in daily life. In the "Ideal Palace", there are not only Islamic mosque-shaped buildings, but also temples full of Hinduism, and even sculptures of characters such as Adam and Eve and Jesus Christ. The author intended to use this strange combination of transformational design methods to change people's perception of the inner style of the world and to give the work a symbolic meaning. Cheval expressed his cognition of the world in this way. The "Ideal Palace" is a unique environment, and the whole environment is advocating his special life concept. He strongly expresses his emotions in his works. This humanistic spirit has made the "Ideal Palace" a unique piece of art in the history of modern art in the world, and has also become the originator of conceptual art such as installation art.

Since 1910, when Marcel Duchamp sent the male urinal named after him to the art center, installation art, an art form that was not well understood by the public, gradually entered the main river of art. Duchamp wanted to express a kind of rebellious spirit and criticize the old traditional artistic concepts with the urinal as an object. He believed that thoughts and 
concepts are the real part of art. The important thing is the artist, the artist's thought, not the work of art. Duchamp's urinal is an off-the-shelf product, and the original attributes of this off-the-shelf product are replaced by the new attributes given by Duchamp, and these objects become works of art that are full of the artist's emotions and thoughts. This is a core idea of installation art. Installation artists believe that people should not only pay attention to the appearance and vision of the work, but also to pay attention to the "thought" in the work. The entity is actually not so important, and the artists are increasingly pursuing personality in the expression of the work, hoping to reach a spiritual resonance with the audience.

Since then, the theme of installation art has become more and more extensive, starting to involve many aspects such as race, war, environmental protection and politics. The social significance of installation art has gradually increased. The artist also continued to experiment with new artistic techniques and began to add abstract elements such as the concept of time and space and spiritual realm to their works, and used these elements to stimulate people's thinking. These are things that traditional art cannot do.

In the 21st century, installation art has become a creative form favored by countless artists. The increase in people's spiritual needs continues to promote the development of installation art. The meaning of installation art changes with the audience, and each audience's interpretation and feeling of art is different. In short, installation art is a comprehensive display of the environment, raw materials and emotions. The pursuit of installation art is to make the audience have a stronger sense of experience and make the audience feel the emotion and self in the works. It interprets the rich humanistic spirit and makes people see the self-worth in the works.

\section{THE MANIFESTATION OF HUMANISM IN ARTISTIC FUNCTIONS}

The social function of art is mainly reflected in three aspects: aesthetic function, cognitive function and educational function. These three aspects exemplify the principle that art serves people. Art exists to allow people to perceive things better, respect life better, and have a better attitude to life.

\section{A. Aesthetic function}

Aesthetic function is the main function of art, mainly focused on the spiritual level of the appreciator. The cognitive function and educational function of art are based on the aesthetic function. In modern society, people pay more attention to self, and spiritual supply has become a necessity for modern people. When people appreciate the artwork, the charm of the artwork will bring the audience a pleasant sense, the viewer can meet their spiritual needs, and their emotions will be pinned. The essential attributes of the artwork also enable the audience to automatically generate this aesthetic behavior. Artists produce various artworks to meet the aesthetic needs of different people. The aesthetic function of art respects the nature of people who love beautiful things. This is why artists emphasize the importance of the humanistic spirit. Art can reflect not only objective reality, but also people's subjective thoughts and emotions. The aesthetic function of art can sublimate the minds of appreciators, and as people's emotional needs become more and more vigorous, people-oriented design concepts are more and more valued. The development of art will be more prosperous.

\section{B. Cognitive function}

The so-called cognitive function refers to people reflecting the objective laws and social phenomena of the development of things through art, understanding life through art, and reproducing society. An excellent artwork will successfully reflect the cultural, moral and humanistic characteristics of the time. For example, one of China's top ten famous paintings, "Riverside Scene at Qingming Festival", when mention this work, people will think of the prosperous scene of Bianjing in the Northern Song Dynasty. The Song Dynasty's society valued the value of people and put people first, which made Song's works of art capable of portraying characters. In "Riverside Scene at Qingming Festival", the painting depicts the scenery of the Northern Song Dynasty's capital and people's life scenes. There are various buildings in the painting: teahouses, restaurants, pharmacies and other shops. Different characters wear different clothes and have different expressions. The paintings depict real scenes, with a strong cultural atmosphere and distinctive artistic features. The author has a profound insight into the life of the Northern Song Dynasty at that time. Through this work, future generations can learn about the commercial, transportation and architectural structure of the Northern Song Dynasty. It has very important literary value.

The creation of such works of art is benefited from the development of the Song Dynasty's humanism ideas, the society values people's values, and the country's attention to people's livelihood. Corresponding works of art can fully show the scenes of people's lives and regard people as the theme of creation.

\section{Educational function}

The educational function of art focuses more on cultivating the emotional level of appreciators. When people's thoughts and emotions are touched, they will be influenced by art in subtle ways. Nowadays, the 
people-oriented concept is deeply ingrained in people's hearts, and the function and significance of art education are gradually paid attention to. The schools pay more attention to the growth of children in many ways. Many schools often carry out art-themed activities, such as poetry recitation, drawing competitions, speech competitions, etc. The school uses these themed activities to stimulate children's curiosity. Art has a huge impact on children. Children who have received art training will have a deeper understanding of life and nature, and will be able to feel beautiful things more sensitively. Art activities are also channels for children to have emotional communication. Starting from the needs of children, effective art activities will enable children to get a sense of self-approval and be greatly satisfied spiritually. Artistic creation can make children give full play to their imagination.

The construction of campus culture has also continued to improve, and the school has begun to create a variety of learning atmospheres. Some school classrooms have different wall styles. For example: the walls on the first floor are famous quotes in foreign literature; the second floor is ancient Chinese poetry in the Tang Dynasty; the third floor is modern prose. Such a design allows children to know this knowledge unconsciously and improve their literature attainment. The educational function of art is irreplaceable.

\section{CONCLUSION}

Humanism has different connotations and expressions in different historical periods. The impact of early humanism on art was manifested as changes in the artist's creative content. Artists were only obsessed with creating architectural sculptures, and began to pay attention to the value of people. Their works mostly depict people's appearance and expression. In modern times, people no longer rely on certain objective criteria to judge art, but judge the value of art only from human feelings. The social function of art is also quite influenced by humanistic thoughts. Whether it is the aesthetic function, the cognitive function or the educational function of art, the starting point and the end point are people themselves, all to make people feel their own value better in art. The influence of humanism on art is far-reaching and lasting, and the function of art is counterproductive to people, improving people's living standards, deepening people's understanding of themselves, and making people's spiritual world richer. The two complement each other and promote each other's development.

\section{References}

[1] Qiu Ruhua, On the Educational Function of Art [J]. New Course Study (Part 1), 2012(1): 163. (in Chinese)
[2] Zhang Qingdan, To See the Spiritual World of Contemporary Art from the Installation Art [J]. Art and Literature for the Masses, 2014, No. 334 04, 134-135. (in Chinese)

[3] Yang Qinqin, On Contemporary Installation Art [J]. Science and Technology, 2009(10), 240+244. (in Chinese)

[4] Wang Huibin, Western Art History Thought and Innovation under the Influence of Renaissance $[\mathrm{J}]$. Research in Arts Education, 2017(23):38. (in Chinese)

[5] Wang Min, Ready-made Art in Public Art [J]. Blooming Season, 2015, 000(012):82-82,83. (in Chinese)

[6] Zhou Gaoxiang, Study the Emotional Expression of Human Historical Themes in Digital Video Art [D]. Nanjing University of the Arts, 2017. (in Chinese) 